\title{
PENGEMBANGAN LEMBAR KEGIATAN SISWA BERBASIS ONLINE BERBANTUAN GEOGEBRA BOOK UNTUK SISWA SMA KELAS X PADA MATERI TRIGONOMETRI
}

\author{
Development of Online-Based Student Activity Sheet with Geogebra Book Aid For \\ Grade X Senior High School Student on Trigonometry Materials
}

\author{
Novita Rizki Yustiani ${ }^{1 *}$ Syaiful Hamzah Nasution ${ }^{2)}$ \\ ${ }^{1}$ Universitas Negeri Malang, Kota Malang, Jawa Timur, novita.rizki41@gmail.com \\ ${ }^{2}$ Universitas Negeri Malang, Kota Malang, Jawa Timur, syaiful.hamzah.fmipa@um.ac.id
}

\begin{abstract}
The implementation of distance learning can not be separated from various problems, including students who are lack of motivation, teachers who find difficulties to work together with parents, and teachers who find difficulties to develop ideas on technology-based learning. To overcome these problems, the student activity sheet which equipped with practice questions and assessments with Geogebra Book aid is already developed as a learning innovation. The material developed in this research is trigonometry with the sub material of graph of trigonometric functions. The research model which used is ADDIE (Analysis, Design, Development, Implement, Evaluate). The research was conducted in SMA Negeri 1 Kepanjen by involving 10 students of social class grade $X$ as test subjects, consisting of 3 students with low ability, 4 students with moderate ability, and 3 students with high ability. Data analysis was measured based on aspects of validity and practicality. Calculation of research data shows that the research product is valid based on an average validity score of $93 \%$ and practical based on an average practicality score of $84 \%$. Based on the results of this data analysis, it can be concluded that the product development of student activity sheet along with practice questions and assessments meets the valid and practical criteria to facilitate students and teachers in the process of learning activities.
\end{abstract}

Keywords: Geogebra, Graph of Trigonometric Functions, Student Worksheet, Development.

\begin{abstract}
ABSTRAK
Pelaksanaan pembelajaran jarak jauh tidak terlepas dari berbagai permasalahan, diantaranya siswa kurang termotivasi, guru merasa kesulitan bekerja sama dengan orang tua siswa, dan guru kesulitan dalam mengembangkan ide-ide pembelajaran berbasis teknologi. Untuk mengatasi hal tersebut, dilakukan pengembangan lembar kegiatan siswa dilengkapi latihan soal dan asesmen berbantuan Geogebra Book sebagai inovasi pembelajaran. Materi yang dikembangkan dalam penelitian adalah trigonometri dengan sub materi grafik fungsi trigonometri. Model penelitian yang digunakan adalah ADDIE (Analysis, Design, Development, Implement, Evaluate). Penelitian dilakukan di SMA Negeri 1 Kepanjen dengan melibatkan siswa kelas X IPS sebanyak 10 siswa sebagai subjek uji coba, terdiri dari 3 siswa berkemampuan rendah, 4 siswa berkemampuan sedang, dan 3 siswa berkemampan tinggi. Analisis data diukur berdasarkan aspek validitas dan praktikalitas. Perhitungan data hasil penelitian menunjukkan bahwa produk penelitian valid berdasarkan rata-rata persentase skor validitas sebesar 93\% dan praktis berdasarkan rata-rata persentase skor praktikalitas sebesar $84 \%$. Berdasarkan hasil analisis data, dapat disimpulkan bahwa produk pengembangan lembar kegiatan siswa beserta latihan soal dan asesmen memenuhi kriteria valid dan praktis untuk memudahkan siswa dan guru dalam proses kegiatan pembelajaran.
\end{abstract}

Kata kunci: Geogebra, Grafik Fungsi Trigonometri, Lembar Kegiatan Siswa, Pengembangan.

\section{PENDAHULUAN}

Wabah pandemi covid-19 dimulai pada akhir tahun 2019. Virus covid-19 menyerang berbagai kalangan, baik dari anak-anak, remaja, dewasa, dan lansia. Menurut data statistik JHU CSSE COVID-19 per tanggal 12 Juli 2021, jumlah masyarakat Indonesia yang tertular virus covid-19 sebanyak 2,57 juta jiwa. Sedangkan jumlah masyarakat Indonesia yang dinyatakan sembuh sebanyak 2,12 juta jiwa dan meninggal dunia sebanyak 67.335 jiwa. 
Sebagai bentuk pencegahan penularan virus covid-19, pemerintah melakukan berbagai upaya. Salah satu upaya tersebut adalah penerapan sistem pembelajaran jarak jauh (Kemendikbud, 2020). Pembelajaran jarak jauh diberlakukan untuk semua tingkat pendidikan, mulai dari sekolah dasar hingga perguruan tinggi (Rohaeti dan Pratiwi, 2021). Menurut Yaumi (2018), pembelajaran jarak jauh (PJJ) adalah pembelajaran formal yang dilaksanakan secara berkelompok namun berpisah tempat, sehingga dibutuhkan teknologi interaktif sebagai penghubung antara siswa, bahan ajar, dan guru. Kurikulum yang diterapkan pada pembelajaran jarak jauh (PJJ) berbeda dari kurikulum pembelajaran yang diterapkan sebelum pandemi. Kurikulum yang diterapkan pada pembelajaran jarak jauh (PJJ) merupakan kurikulum yang disederhanakan, dimana guru tidak diwajibkan untuk memenuhi ketuntasan Kompetensi Inti (KI) maupun Kompetensi Dasar (KD).

Pada kegiatan pembelajaran jarak jauh (PJJ) tentu saja banyak kendala atau permasalahan yang dialami. Permasalahan tersebut dialami oleh siswa, guru, maupun orang tua siswa atau wali murid, diantaranya: (1) Siswa kurang termotivasi; (2) Guru merasa kesulitan bekerja sama dengan orang tua siswa. Tidak sedikit orang tua siswa yang kurang peduli dan menyerahkan sepenuhnya kegiatan pembelajaran jarak jauh kepada guru di sekolah; (3) Guru kesulitan membuat Rancangan Pelaksanaan Pembelajaran Jarak Jauh dimana guru dituntut untuk mengembangkan ide-ide kreatif, yang tentu saja berbeda dari pembelajaran tatap muka langsung, dengan menggunakan media teknologi (Sarwa, 2021). Permasalahan tersebut juga terjadi di SMA Negeri 1 Kepanjen. Menurut salah satu guru matematika kelas X, permasalahan yang dihadapi selama pembelajaran jarak jauh adalah siswa kurang termotivasi dan beberapa guru kesulitan dalam mengembangkan ide-ide pembelajaran menggunakan media teknologi, terutama pada mata pelajaran matematika. Hal ini menyebabkan adanya keterlambatan beberapa siswa dalam memahami dan menguasai materi pada mata pelajaran matematika. Sebagai solusi atas permasalahan tersebut, dibutuhkan inovasi atau pengembangan terhadap sistem pembelajaran, salah satunya pada bahan ajar. Bahan ajar yang dapat diterapkan dalam pembelajaran jarak jauh adalah Lembar Kegiatan Siswa (LKS) (Lestari et al., 2018).

Menurut Rahma dan Arista (2019), LKS adalah salah satu bahan ajar yang dibuat dan disusun oleh guru untuk siswa berupa lembaran berisi informasi dan instruksi. Penggunaan LKS membantu guru untuk mengarahkan siswa dalam menemukan serta memahami konsep-konsep terkait materi ajar melalui aktivitas pada LKS (Ismaraidha, 2021). Hal tersebut selaras dengan tujuan pengembangan LKS pada pembelajaran jarak jauh, yaitu menghasilkan bahan ajar yang mudah diakses oleh siswa maupun guru, memudahkan siswa dan guru dalam proses pembelajaran, serta membantu siswa memahami materi ajar selama kegiatan pembelajaran jarak jauh.

Seiring berjalannya sistem pembelajaran jarak jauh, dibutuhkan bahan ajar yang dapat dikerjakan kapan saja dan di mana saja. Salah satu bentuk bahan ajar yang dapat digunakan dalam pembelajaran jarak jauh yaitu LKS berbantuan Geogebra. Geogebra adalah perangkat lunak bersifat dinamis yang sering digunakan sebagai alat bantu dalam bidang matematika. Menurut Azizul dan Din (2016), Geogebra dapat digunakan dalam pembelajaran matematika berbasis teknologi. Perangkat lunak Geogebra dapat dimanfaatkan sebagai sarana dalam meningkatkan pemahaman siswa terhadap konsep yang telah dipelajari maupun sebagai sarana pengenalan konsep baru terkait materi pelajaran matematika (Nur, 2016).

Salah satu fasilitas pada Geogebra yang digunakan untuk membuat atau merancang lembar kegiatan siswa secara online adalah Geogebra Activity. Menurut Horsum dan Ünlü (2017), Geogebra Activity memungkinkan pengguna untuk mendesain atau merancang kegiatan pembelajaran matematika serta membantu pengguna untuk mengajar matematika dengan lebih baik, khususnya trigonometri. Kemudian untuk mengumpulkan materi dan lembar kegiatan siswa dalam satu kesatuan dapat menggunakan Geogebra Book. Geogebra Book adalah koleksi materi dan aktivitas berbasis Geogebra yang memungkinkan pengorganisasian menjadi satu kesatuan yang dibuat dari Geogebra (Galicia et al., 2018).

Berdasarkan observasi pendahuluan yang telah dilakukan oleh peneliti di SMA Negeri 1 Kepanjen, didapatkan informasi bahwa pembelajaran matematika belum pernah menggunakan bahan ajar LKS 
berbantuan Geogebra. Sehingga lembar kegiatan siswa berbantuan Geogebra dapat dikembangkan. Telah ada penelitian sebelumnya tentang Geogebra Activity pada bidang matematika yang bertujuan untuk meneliti sudut pandang pengajar tentang Geogebra dan penggunaanya setelah mereka mengetahui bagaimana cara merancang LKS menggunakan Geogebra Activity (Horsum dan Ünlü, 2017). Berdasarkan hal tersebut, peneliti ingin melakukan penelitian pengembangan lembar kegiatan siswa dilengkapi latihan soal dan asesmen berbasis online berbantuan Geogebra Book untuk siswa SMA kelas X pada materi trigonometri yang valid serta praktis.

\section{METODE}

Metode penelitian yang digunakan adalah penelitian pengembangan (Research and Deveopment). Produk pembelajaran pada penelitian pengembangan berupa lembar kegiatan siswa dilengkapi latihan soal dan asesmen. Model penelitian pengembangan yang digunakan adalah ADDIE. Model penelitian ADDIE terdiri atas lima tahapan yaitu analisis (analysis), desain (design), pengembangan (development), implementasi (implement), dan evaluasi (evaluate). ADDIE adalah salah satu model penelitian tentang desain pada sistem pembelajaran yang menyajikan tahapan dasar dan mudah dilakukan (Cahyadi, 2019).

Penelitian dilakukan pada bulan Juni 2021 di SMA Negeri 1 Kepanjen dengan melibatkan siswa kelas X IPS sebanyak 10 siswa sebagai subjek uji coba, terdiri atas 3 siswa berkemampuan rendah, 4 siswa berkemampuan sedang, dan 3 siswa berkemampuan tinggi. Produk penelitian yang dikembangkan kemudian dianalisis tingkat validitas dan praktikalitas berdasarkan data yang diperoleh dari lembar validasi dan lembar angket respons. Penilaian validitas dan praktikalitas terdiri atas lembar kegiatan siswa (LKS), latihan soal, dan asesmen. Penilaian validitas menggunakan lembar validasi yang dilakukan oleh dosen Jurusan Matematika UM. Sedangkan penilaian praktikalitas menggunakan lembar angket respons yang dilakukan oleh guru dan siswa SMA Negeri 1 Kepanjen.

Penelitian pengembangan menggunakan data kualitatif dan kuantitatif. Data kualitatif didapatkan dari saran atau komentar yang terdapat pada lembar validasi, lembar angket respons guru, dan lembar angket respons siswa setelah menggunakan lembar kegiatan siswa berbantuan Geogebra. Sedangkan data kuantitatif didapatkan dari skor validasi atau validitas, skor angket respons guru, dan skor angket respons siswa.

Data kuantitatif dianalisis berdasarkan dua aspek, yaitu:

\section{Aspek Validitas}

Validitas merupakan suatu ukuran ketepatan antara data yang terjadi pada objek yang diteliti dengan data yang dilaporkan oleh peneliti (Hardani et al., 2020). Uji validitas dapat dihitung dengan rumus berikut:

$$
V=\frac{\sum x}{\sum x_{i}} \times 100 \%
$$

Keterangan:

$V \quad:$ Persentase validitas

$x \quad$ : Jumlah skor yang diperoleh

$x_{i} \quad$ Jumlah skor maksimum tiap kriteria

Sebagai bahan pertimbangan dalam pengambilan keputusan untuk merevisi produk penelitian pengembangan digunakan kategori penilaian. Kategori penilaian aspek validitas ditampilkan pada Tabel 1. 
Tabel 1. Kategori Validitas

\begin{tabular}{|c|c|}
\hline Interval Persentase & Kategori \\
\hline $80 \% \leq V \leq 100 \%$ & Sangat Valid \\
\hline $60 \% \leq V<80 \%$ & Valid \\
\hline $40 \% \leq V<60 \%$ & Cukup Valid \\
\hline $20 \% \leq V<40 \%$ & Kurang Valid \\
\hline $0 \% \leq V<20 \%$ & Tidak Valid \\
\hline
\end{tabular}

Sumber: (Sari et al., 2021)

Produk penelitian dinyatakan valid apabila persentase rata-rata skor validitas termasuk dalam kategori minimal valid (Susanto dan Retnawati, 2016). Artinya, persentase minimal yang harus didapatkan agar produk penelitian dinyatakan valid adalah $60 \%$.

\section{Aspek Praktikalitas}

Praktikalitas diukur dari aspek penyajian dan aspek kemudahan penggunaan (Agustyaningrum, 2017). Uji praktikalitas dapat dihitung dengan rumus berikut:

$$
V=\frac{\sum x}{\sum x_{i}} \times 100 \%
$$

Keterangan:

$V \quad:$ Persentase praktikalitas

$x \quad$ : Jumlah skor yang diperoleh

$x_{i} \quad$ : Jumlah skor maksimum tiap kriteria

Sebagai acuan untuk penilaian praktikalitas digunakan kategori penilaian. Kategori penilaian aspek praktikalitas ditampilkan pada Tabel 2.

Tabel 2. Kategori Praktikalitas

\begin{tabular}{|c|c|}
\hline Interval Persentase & Kategori \\
\hline $80 \% \leq V \leq 100 \%$ & Sangat Praktis \\
\hline $60 \% \leq V<80 \%$ & Praktis \\
\hline $40 \% \leq V<60 \%$ & Cukup Praktis \\
\hline $20 \% \leq V<40 \%$ & Kurang Praktis \\
\hline $0 \% \leq V<20 \%$ & Tidak Praktis \\
\hline
\end{tabular}

Sumber: (Sari et al., 2021)

Produk penelitian dinyatakan praktis apabila persentase rata-rata skor praktikalitas termasuk dalam kategori minimal praktis (Maharani et al., 2021). Artinya, persentase minimal yang harus didapatkan agar produk penelitian dinyatakan praktis adalah $60 \%$.

\section{HASIL DAN PEMBAHASAN}

Produk penelitian pengembangan berupa lembar kegiatan siswa, latihan soal, dan asesmen. Aplikasi yang digunakan untuk lembar kegiatan siswa adalah Geogebra. Sedangkan untuk latihan soal dan asesmen menggunakan aplikasi Google Form. Fasilitas yang digunakan untuk memuat lembar kegiatan siswa, latihan soal, dan asesmen adalah Geogebra Book. Hasil dari tahapan penelitian dan pengembangan ADDIE diuraikan sebagai berikut.

Analisis adalah usaha untuk mengamati sesuatu secara detail kemudian diuraikan pokok permasalahannya untuk dikaji lebih lanjut (Manurung, 2015). Pada tahap analisis, peneliti melakukan observasi awal menggunakan metode wawancara dengan salah satu guru matematika di SMAN 1 Kepanjen. Dari wawancara tersebut, didapatkan hasil bahwa banyak permasalahan yang dihadapi 
pada pelaksanaan kegiatan pembelajaran jarak jauh. Diantaranya siswa yang kurang motivasi hingga permasalahan jaringan ketika pembelajaran tatap muka secara daring. Sebagai solusi untuk permasalahan ini dibutuhkan bahan ajar atau media ajar yang memudahkan siswa dan guru selama kegiatan pembelajaran jarak jauh yang dapat diakses kapan saja dan dimana saja serta dapat memahamkan siswa terkait materi matematika. Oleh karena itu, peneliti melakukan pengembangan LKS beserta latihan soal dan asesmen berbasis online berbantuan Geogebra Book.

Desain adalah kegiatan merancang sesuatu dalam rangka tujuan kemudahan (Rucitra, 2020). Pada tahap desain, peneliti membuat gambaran terkait produk pengembangan LKS beserta latihan soal dan asesmen berbantuan Geogebra Book. Rencana isi LKS berupa tahap-tahap menggambar atau menentukan bentuk grafik fungsi trigonometri sinus dan cosinus dalam fungsi tertentu (selengkapnya bisa diakses melalui tautan https://www.geogebra.org/m/ck2cr7g3). Rancangan desain produk pembelajaran disajikan dalam storyboard. Berikut storyboard produk pembelajaran yang ditampilkan pada Gambar 1, 2, dan 3.

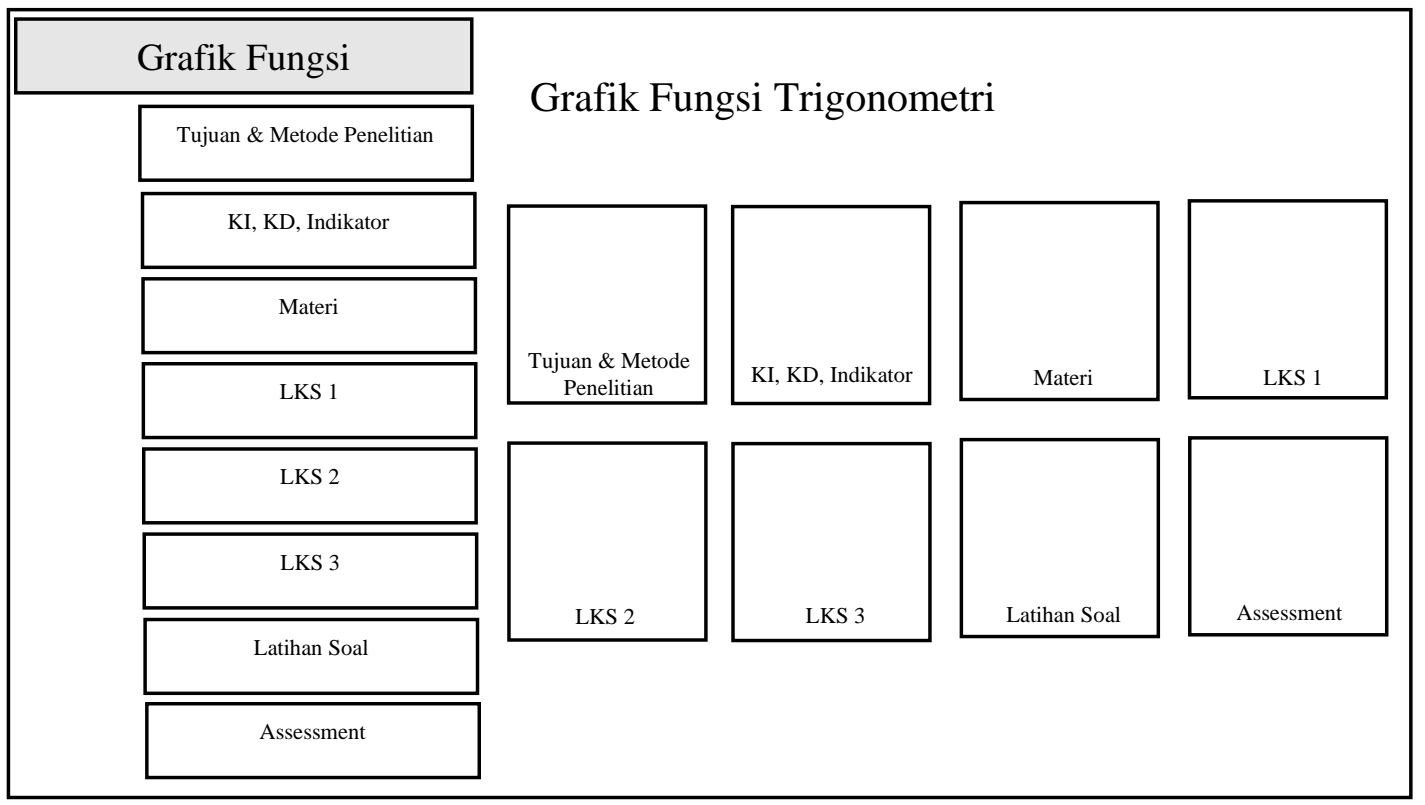

Gambar 1. Storyboard Menu Utama

Sumber: dokumen pribadi

\begin{tabular}{|c|c|}
\hline Grafik Fungsi & \multirow{9}{*}{$\begin{array}{l}\text { Latihan Soal Grafik Fungsi } \\
\text { Trigonometri } \\
\text { Silahkan ikuti tautan berikut: } \\
\text { (Tautan) }\end{array}$} \\
\hline Tujuan \& Metode & \\
\hline $\mathrm{KI}, \mathrm{KD}$, Indikator & \\
\hline Materi & \\
\hline LKS 1 & \\
\hline LKS 2 & \\
\hline LKS 3 & \\
\hline Lathan Soal & \\
\hline Asesmen & \\
\hline
\end{tabular}

Gambar 2. Storyboard Halaman Latihan Soal

Sumber: dokumen pribadi 


\begin{tabular}{|c|c|}
\hline Grafik Fungsi & \multirow{2}{*}{$\begin{array}{l}\text { Asesmen Grafik Fungsi Trigonometri } \\
\text { Silahkan ikuti tautan berikut: } \\
\text { (Tautan) }\end{array}$} \\
\hline Tujuan \& Metode \\
\hline \hline KI, KD, Indikator \\
\hline \hline Materi \\
\hline \hline LKS 1 \\
\hline \hline LKS 2 \\
\hline LKS 3 \\
\hline Latihan Soal \\
\hline Asesmen \\
\hline
\end{tabular}

Gambar 3. Storyboard Halaman Asesmen

Sumber: dokumen pribadi

Pengembangan adalah upaya atau usaha dalam rangka tujuan peningkatan agar menjadi lebih baik (Ningrum, 2016). Pada tahap pengembangan (development), peneliti melakukan pengembangan produk dari storyboard ke bentuk produk sebenarnya. Gambar 4 merupakan tampilan pembuka. Di dalamnya terdapat menu yang dapat dipilih oleh pengguna.

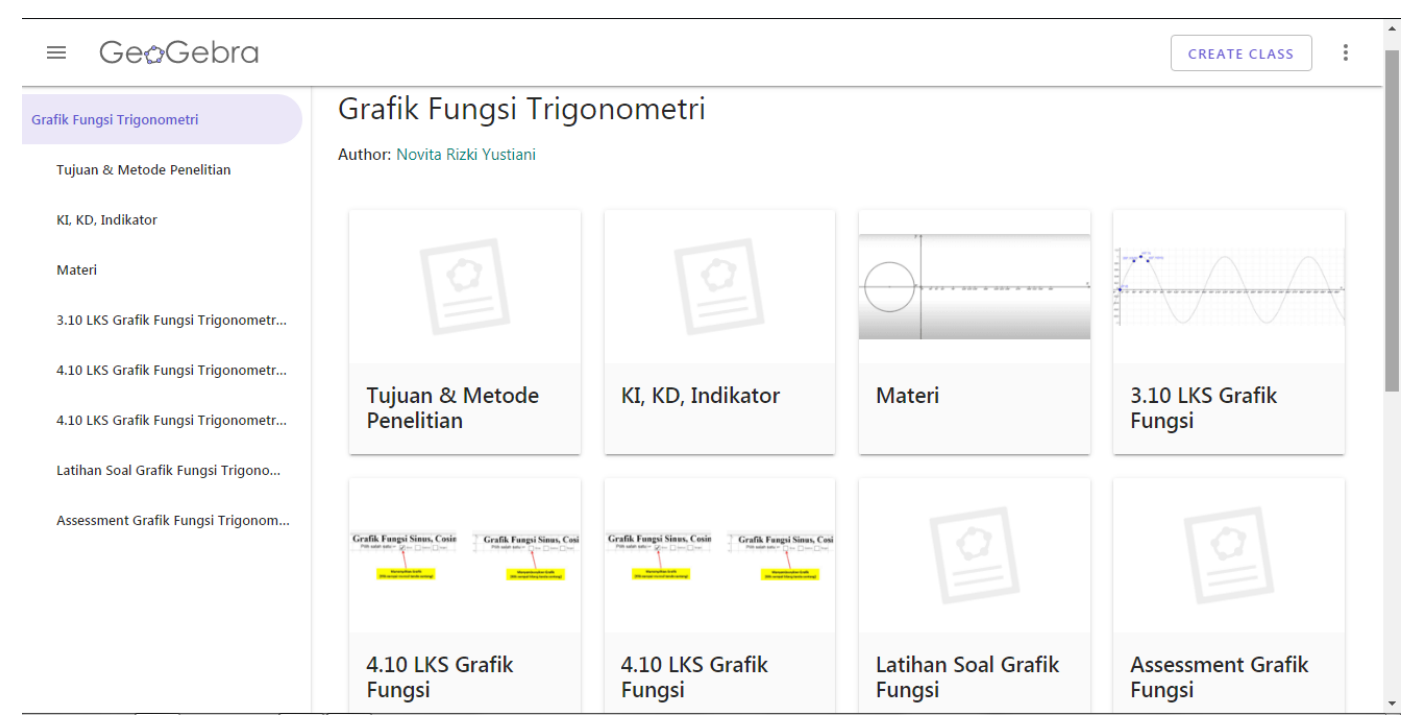

Gambar 4. Tampilan Awal Geogebra Book

Sumber: dokumen pribadi 
Selanjutnya, Gambar 5 merupakan tampilan Geogebra Book berisi tujuan dan metode penelitian.

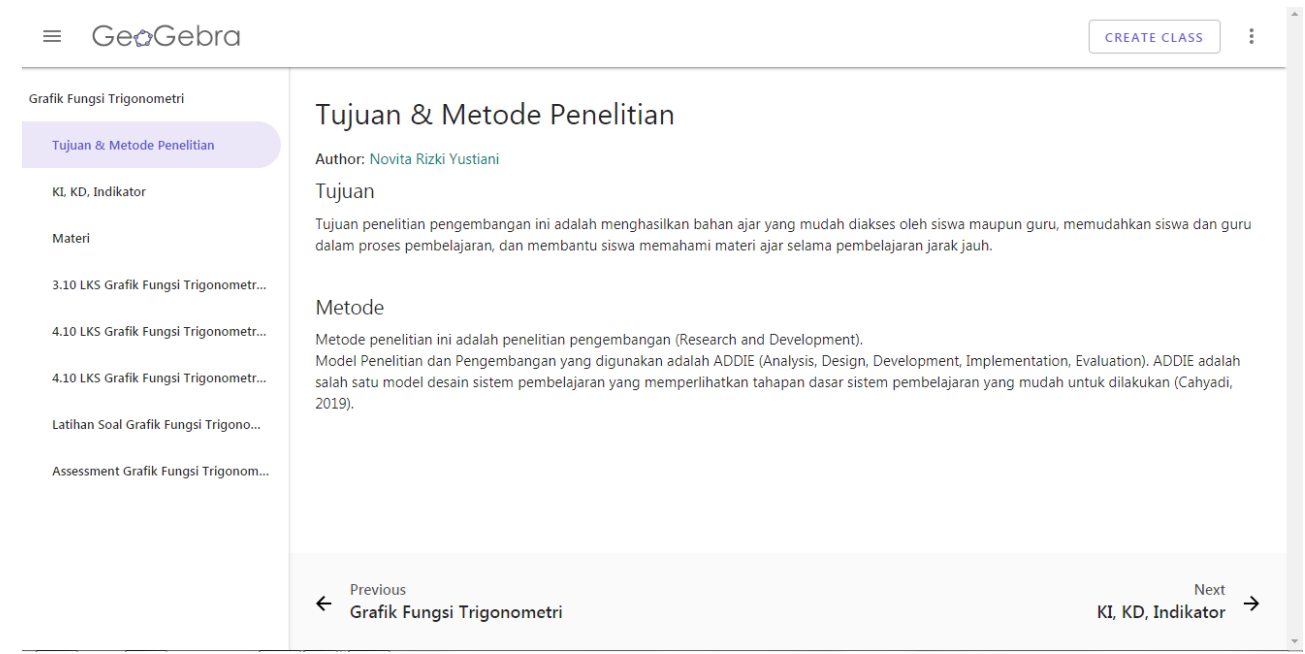

Gambar 5. Tampilan Tujuan dan Metode Penelitian

Sumber: dokumen pribadi

Kemudian, Gambar 6 merupakan tampilan Geogebra Book berisi kompetensi inti (KI), kompetensi dasar (KD), dan Indikator.

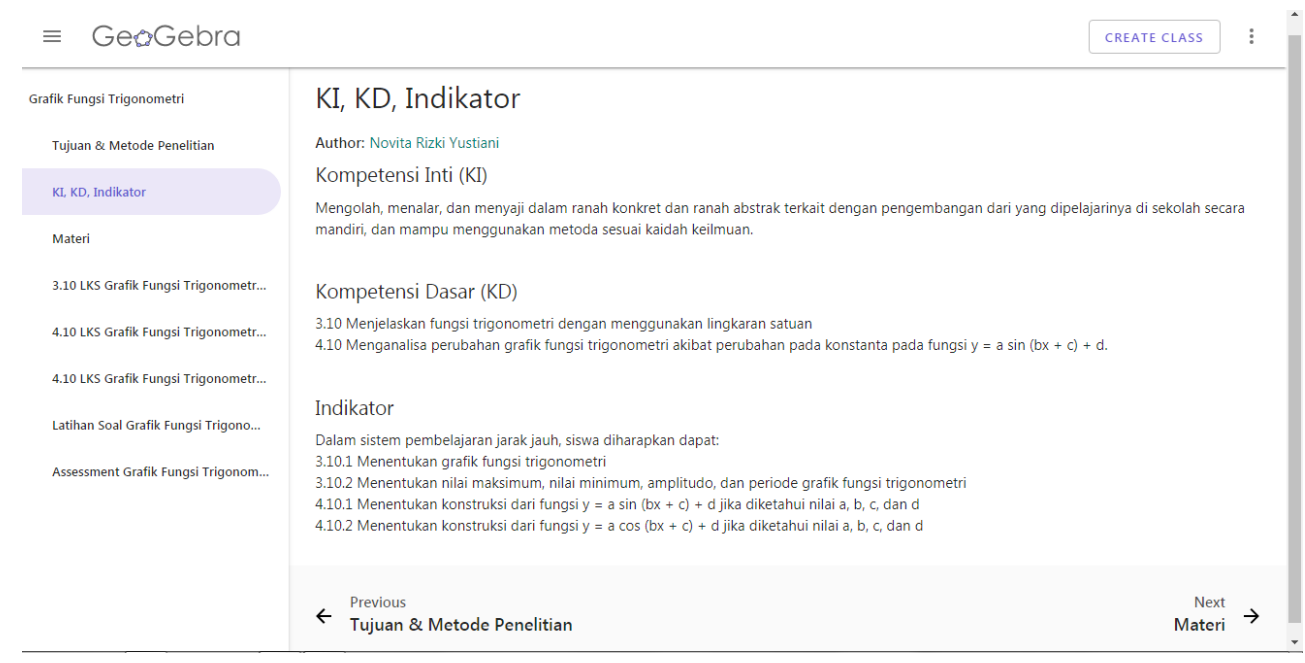

Gambar 6. Tampilan KI, KD, dan Indikator

Sumber: dokumen pribadi

Selanjutnya, Gambar 7 merupakan tampilan Geogebra Book berisi materi grafik fungsi trigonometri. 


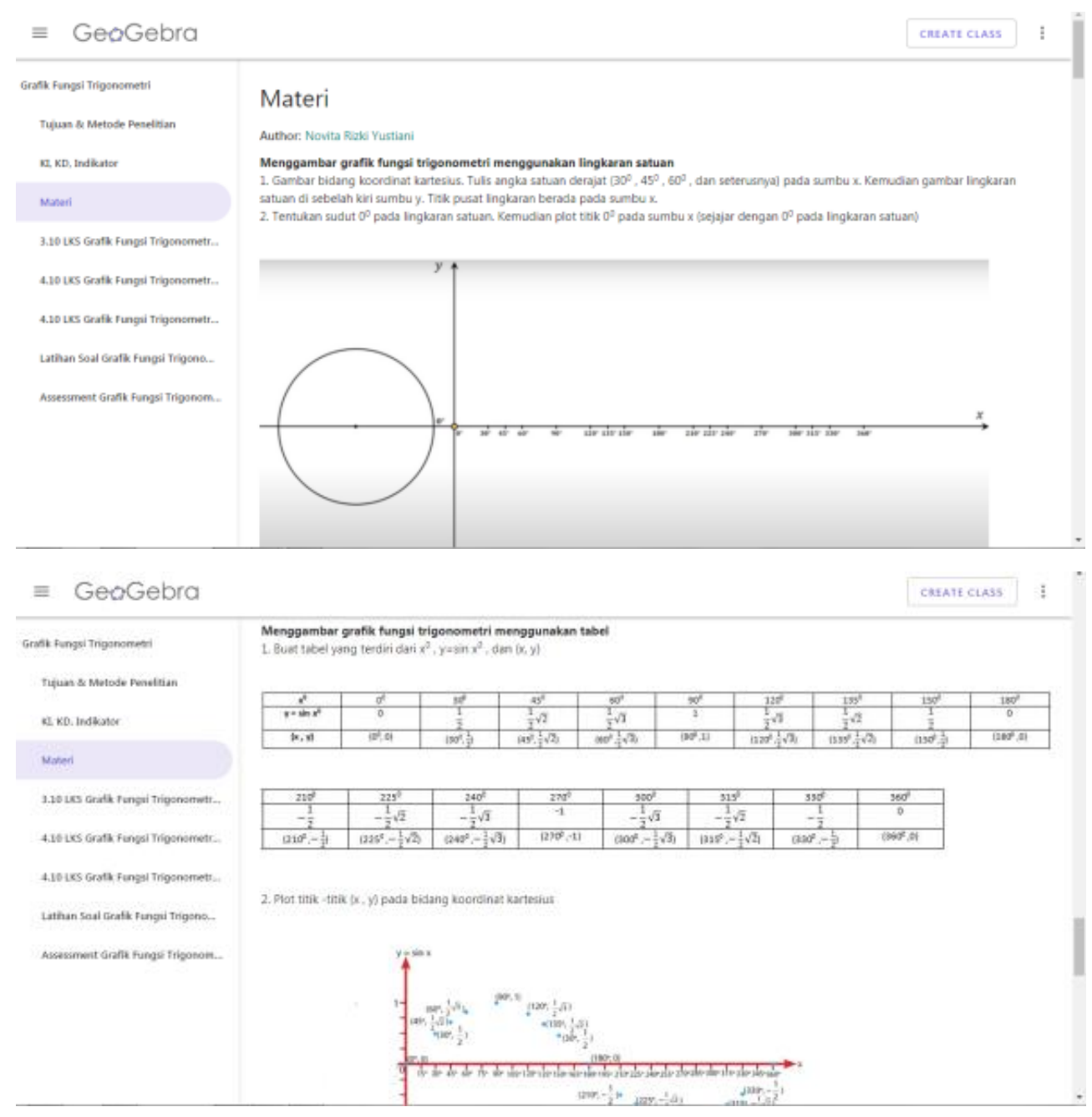

Gambar 7. Tampilan Materi Grafik Fungsi Trigonometri

Sumber: dokumen pribadi

Lembar Kegiatan Siswa yang mengacu pada KD 3.10 ditampilkan pada Gambar 8. Lembar Kegiatan Siswa fokus pada materi sinus.

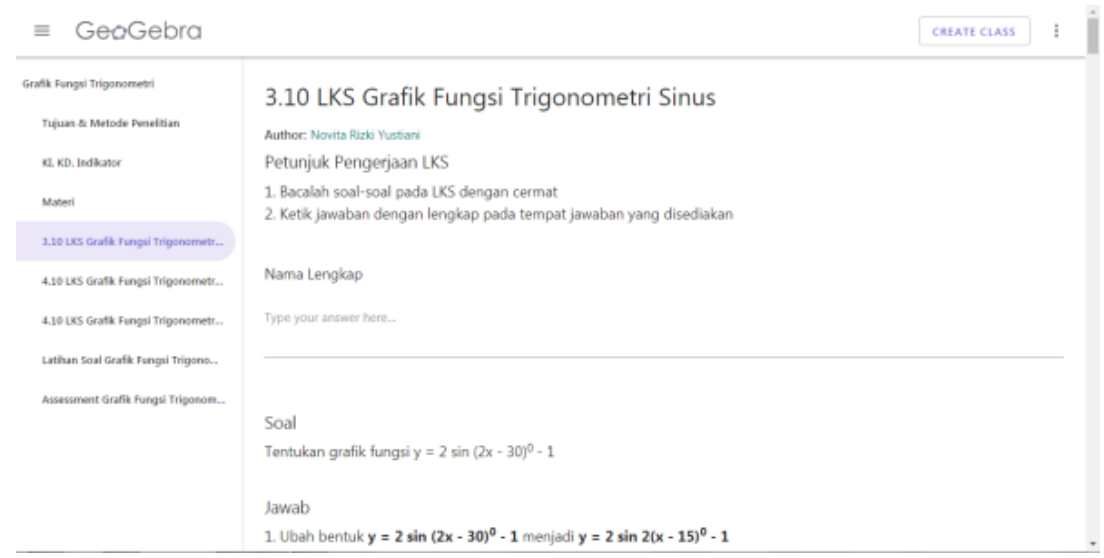

Gambar 8. Tampilan LKS KD 3.10

Sumber: dokumen pribadi 
Selain materi dan lembar kegiatan siswa, terdapat latihan soal dan asesmen. Kedua perangkat tersebut memanfaatkan platform Google Form. Tampilan latihan soal disajikan pada Gambar 9.

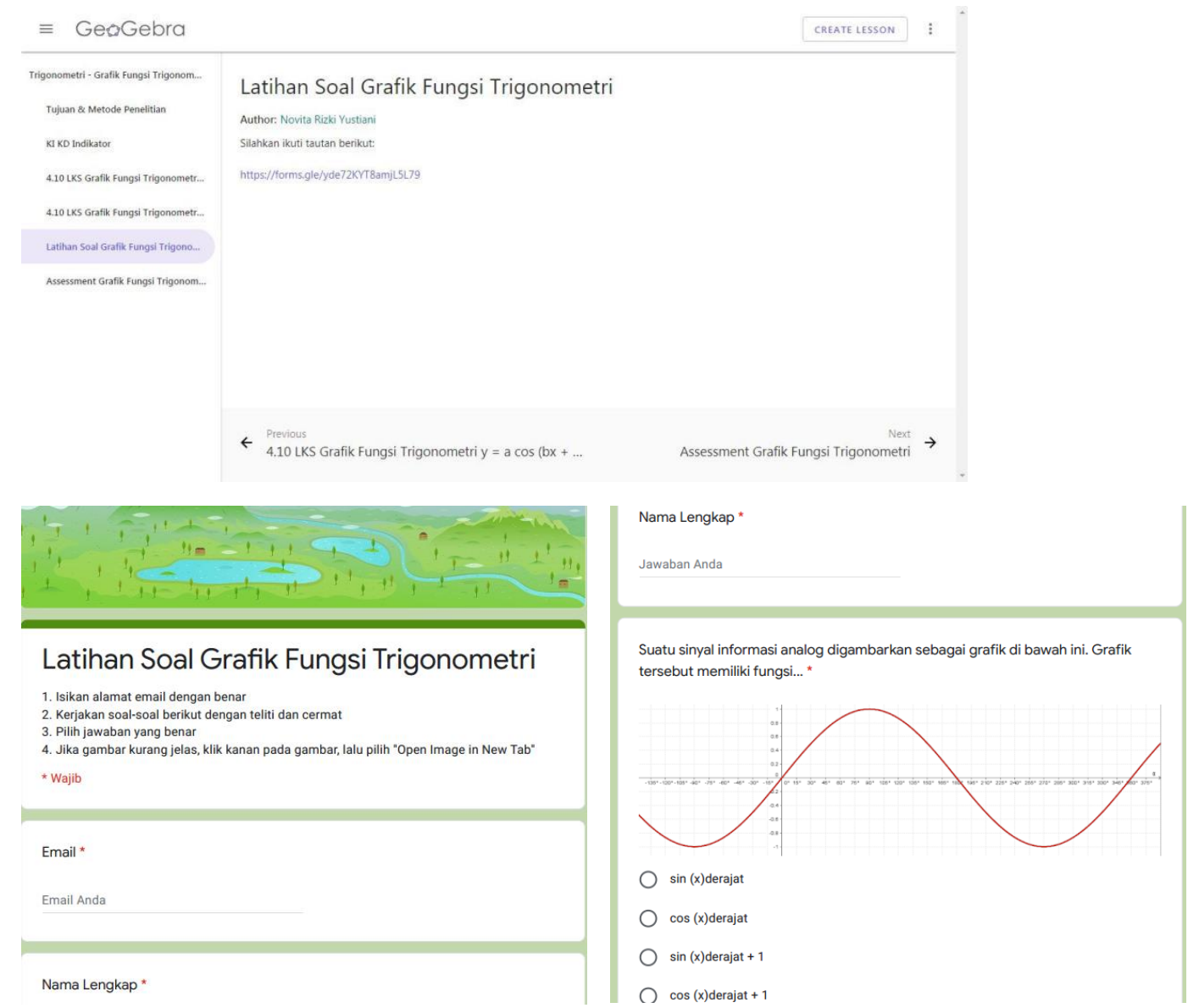

Gambar 9. Tampilan Latihan Soal

Sumber: dokumen pribadi

Kemudian, asesmen juga memanfaatkan platform Google Form. Tampilan asesmen disajikan pada Gambar 10.

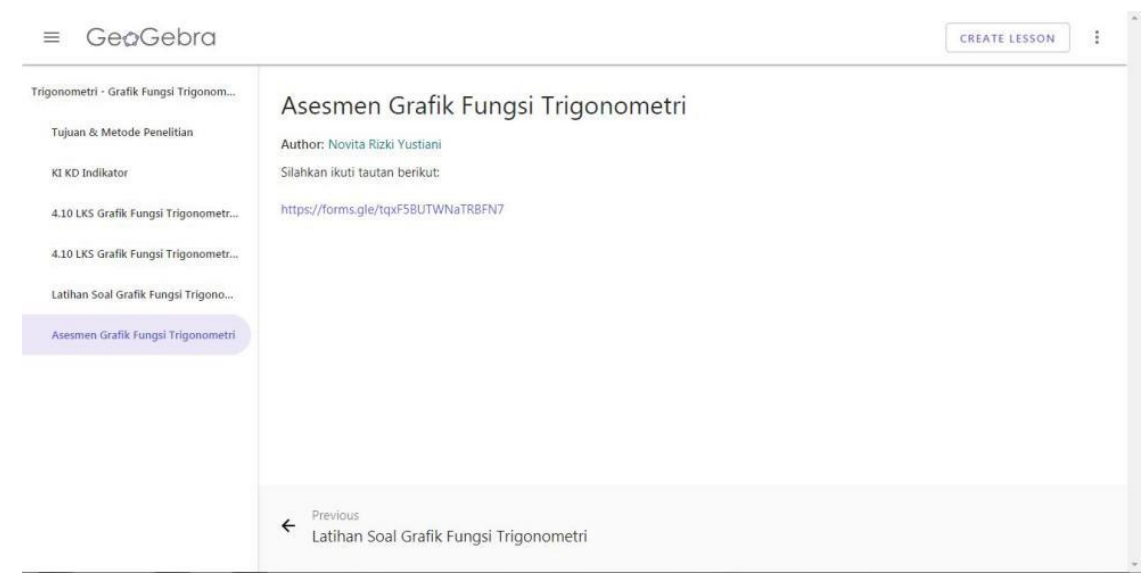




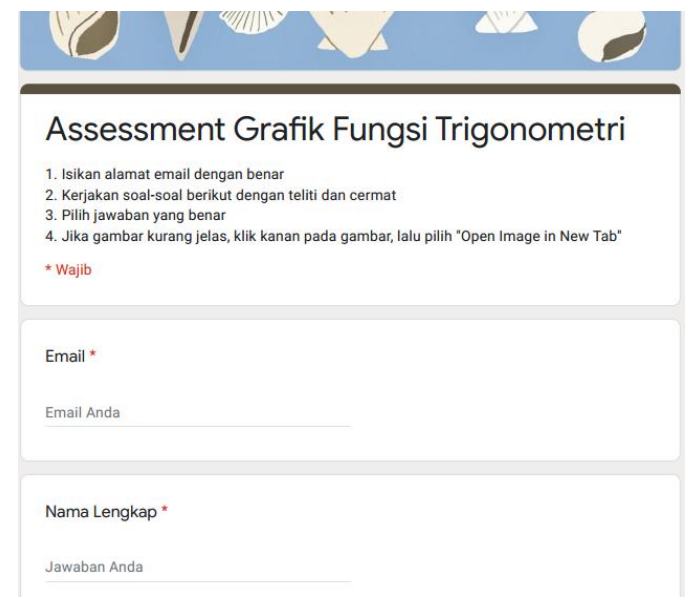

Grafik di bawah merupakan grafik fungsi $y=\cos (2 x+30)$ derajat. Jika posisi grafik tersebut digeser sejauh 15 derajat ke kanan, kemudian digeser sejauh 2 satuan ke bawah, maka persamaan grafik menjadi... *

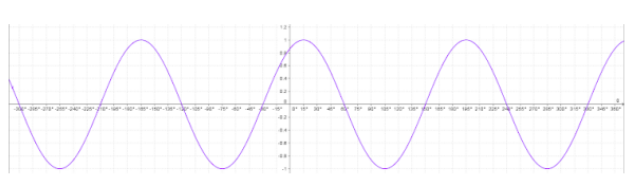

$y=-2 \cos (2 x+15)$ derajat +5

$y=-2 \cos (2 x+15)$ derajat -5

$y=\cos (2 x+15)$ derajat -2

$y=\cos (2 x+45)$ derajat -2

Untuk mendukung pemantauan kapal laut dibutuhkan suatu sistem komunikas maritim. Suatu saat terdapat kapal sedang mengirimkan sinyal informasi yang digambarkan sebagai grafik dengan fungsi $y=2 \sin (2 x+45)$ derajat. Manakah

\section{Gambar 10. Tampilan Asesmen}

Sumber: dokumen pribadi

Agar memenuhi kriteria validitas, produk penelitian yaitu lembar kegiatan siswa beserta latihan soal dan asesmen yang dikembangkan telah melalui proses revisi. Terdapat revisi lembar kegiatan siswa berdasarkan saran dan masukan dari dosen validator. Berikut ini lembar kegiatan siswa berbantuan Geogebra Book sebelum dan sesudah revisi yang ditampilkan pada Gambar 11 dan Gambar 12.

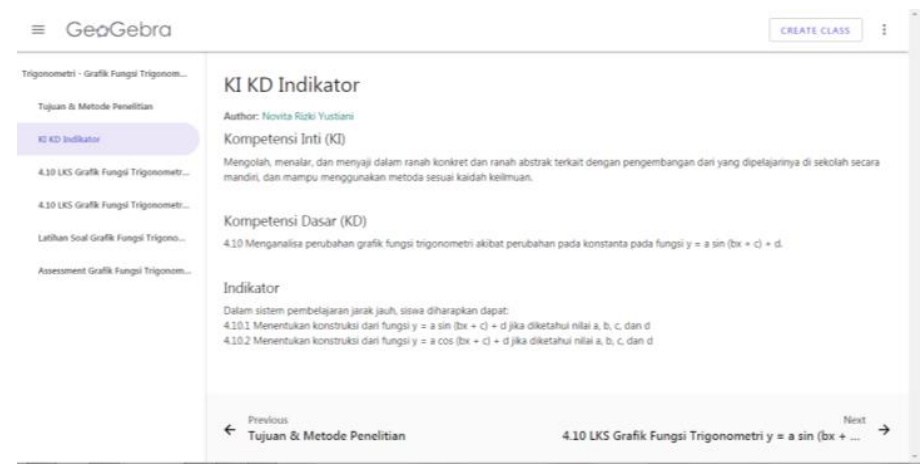

(a)

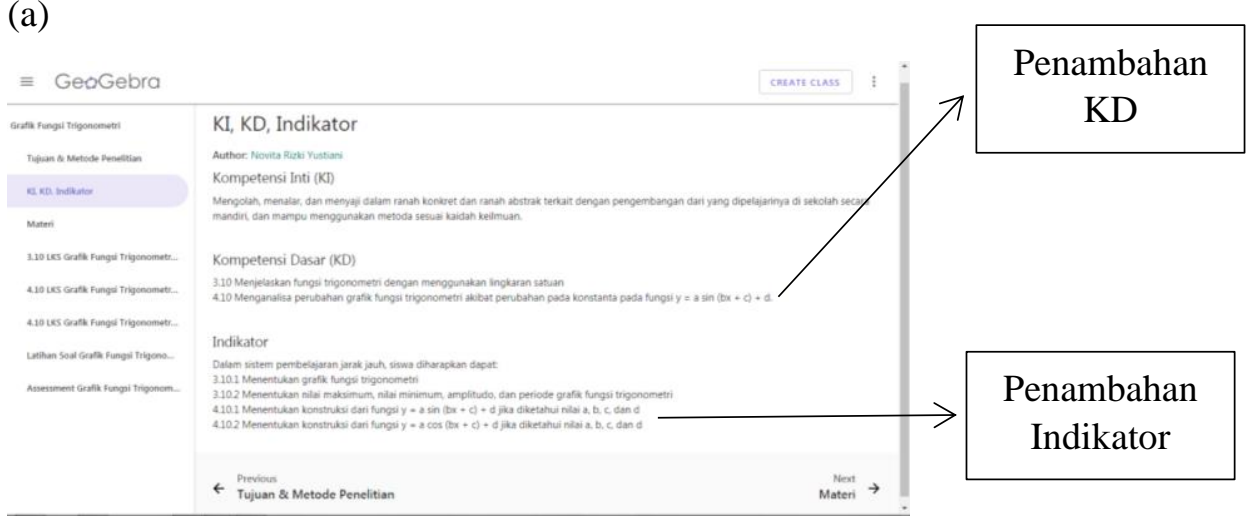

(b)

Gambar 11. Tampilan KD dan Indikator Sebelum Revisi (a) dan Sesudah Revisi (b)

Sumber: dokumen pribadi 


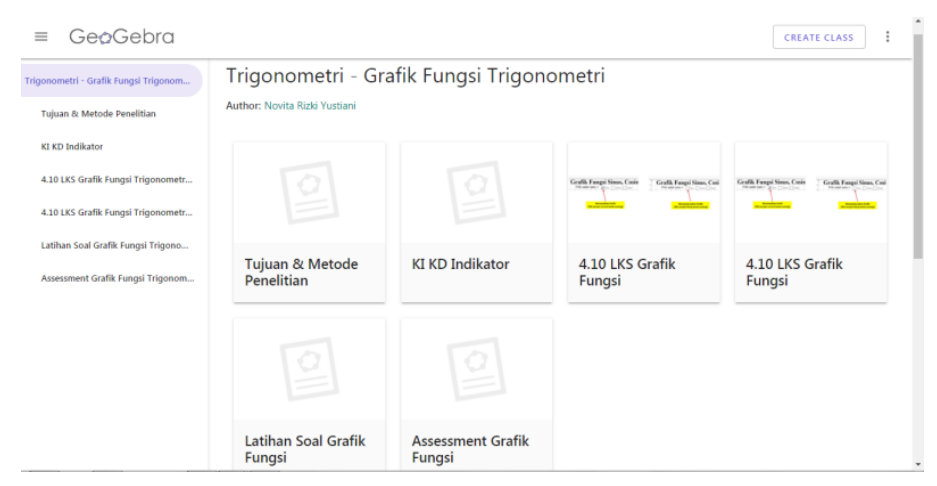

(a)

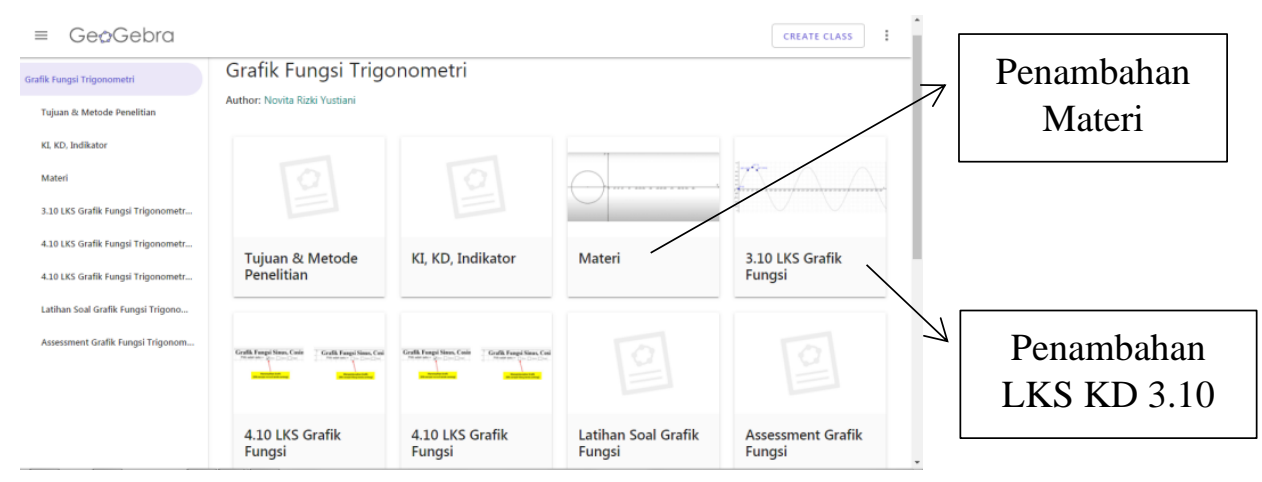

(b)

Gambar 12. Tampilan Geogebra Book Sebelum Revisi (a) dan Sesudah Revisi (b)

Sumber: dokumen pribadi

Implementasi adalah suatu aktivitas atau tindakan untuk melaksanakan suatu sistem yang telah dibuat (Tampubolon et al., 2013). Pada tahap implementasi, peneliti menggunakan produk dan melakukan penelitian melalui pembelajaran daring di SMAN 1 Kepanjen. Komunikasi antara peneliti dengan guru maupun peneliti dengan siswa selaku subjek penelitian dilakukan menggunakan media komunikasi WhatsApp. Selanjutnya siswa dipandu untuk membuat akun Geogebra kemudian bergabung dalam kelas Geogebra. Setelah siswa berhasil masuk kelas Geogebra, siswa akan disajikan Geogebra Book berisi materi, LKS, latihan soal, dan asesmen. Sebelum lanjut ke tahap pengerjaan LKS, siswa diarahkan untuk membaca dan memahami materi yang diberikan, yaitu tentang grafik fungsi trigonometri. Setelah membaca dan memahami materi, siswa mengerjakan LKS, latihan soal, dan asesmen. Berikut cuplikan kegiatan penelitian yang disajikan pada Gambar 13 dan Gambar 14. 


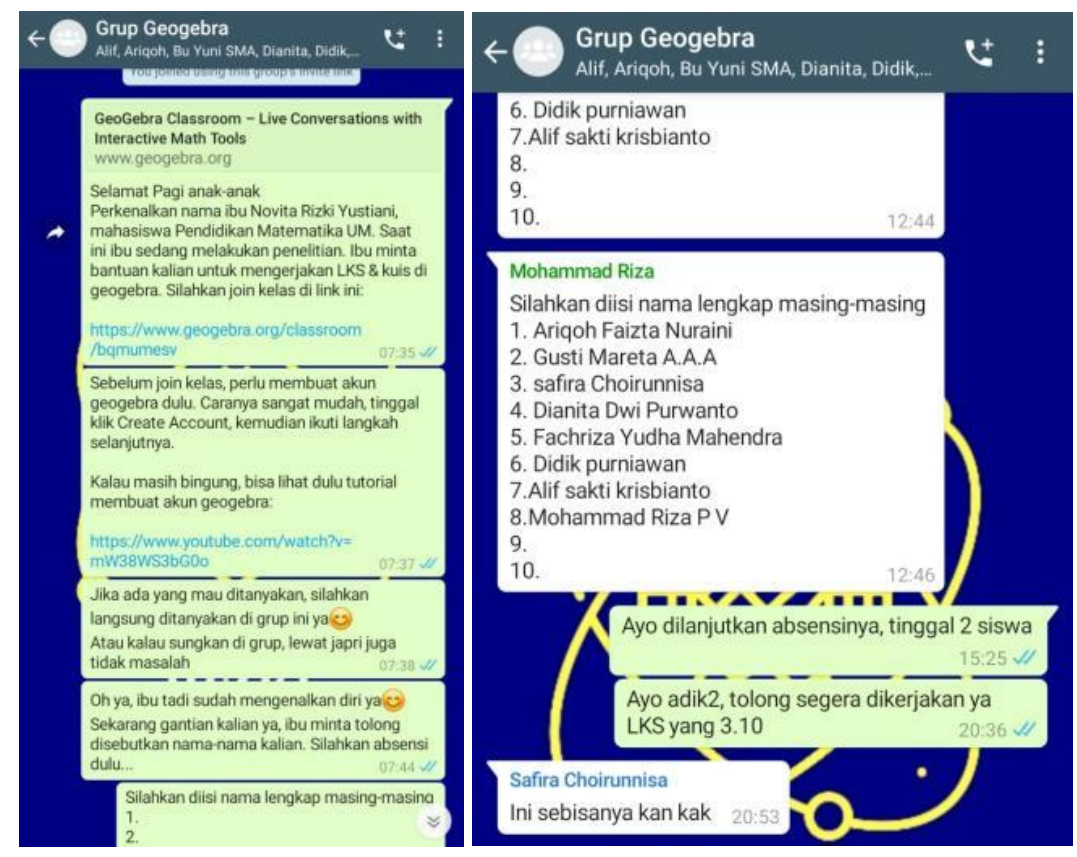

Gambar 13. Komunikasi Kegiatan Pembelajaran Melalui WhatsApp

Sumber: dokumen pribadi

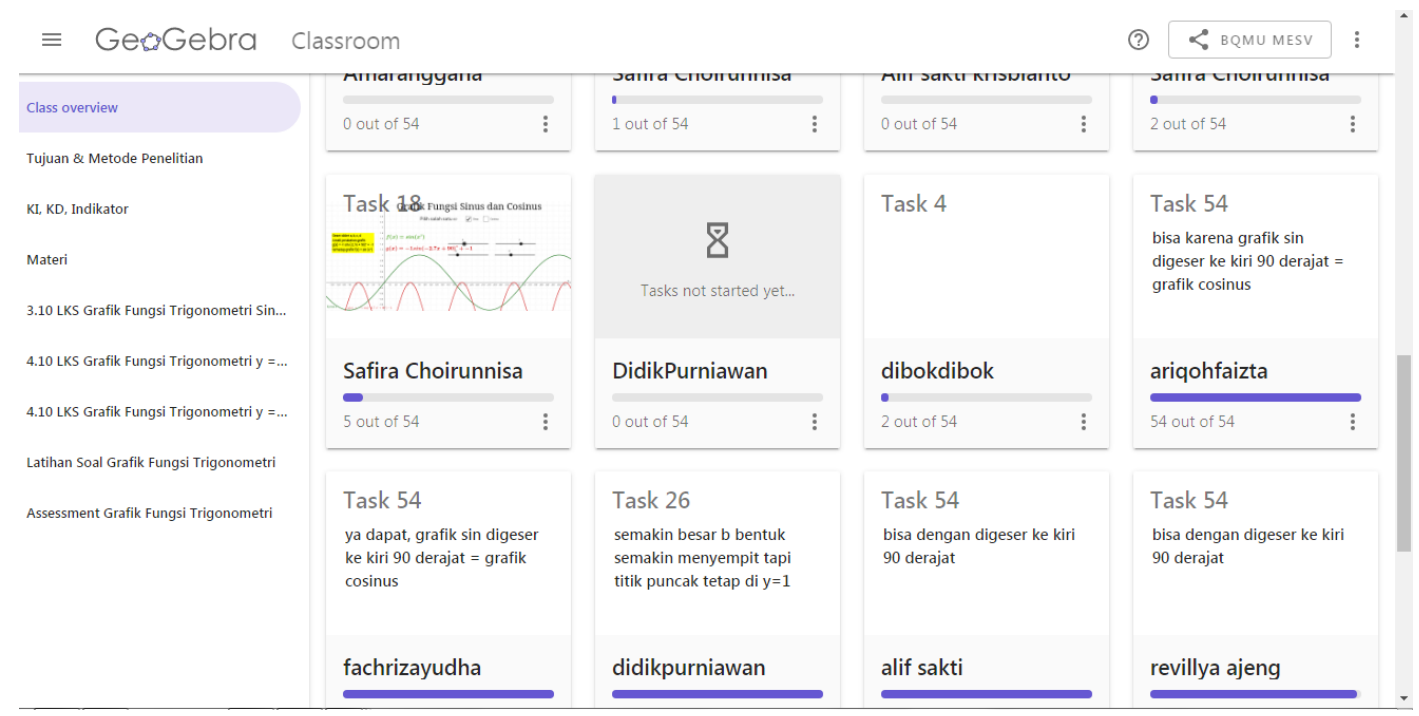

Gambar 14. Record Siswa yang Mengerjakan LKS

Sumber: dokumen pribadi

Analisis data diukur berdasarkan aspek validitas dan praktikalitas. Data validitas diperoleh dari validator. Hasil validitas terhadap produk penelitian pengembangan berupa lembar kegiatan siswa (LKS), latihan soal, dan asesmen ditampilkan dalam bentuk diagram batang pada Gambar 15. 


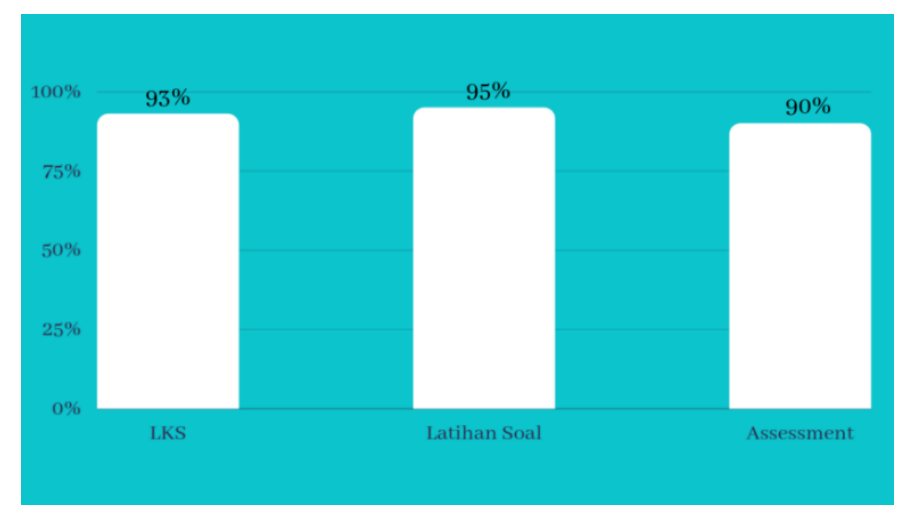

Gambar 15. Diagram Hasil Validasi

Sumber: dokumen pribadi

Rata-rata persentase hasil validasi adalah 93\%. Persentase tersebut menunjukkan bahwa produk penelitian pengembangan masuk dalam kategori "Sangat Valid" oleh validator.

Data praktikalitas diperoleh dari angket guru dan angket siswa. Hasil praktikalitas terhadap produk penelitian pengembangan ditampilkan pada Tabel 3 .

Tabel 3. Hasil Praktikalitas

\begin{tabular}{|c|c|c|c|c|c|c|c|c|c|c|c|c|c|c|c|c|c|c|c|}
\hline Subjek & \multicolumn{18}{|c|}{ Skor Tiap Kriteria } & Persentase \\
\hline Guru & 3 & \begin{tabular}{|l|}
3 \\
\end{tabular} & & & 3.3 & 3 & & 3 & 3 & 3 & 3 & 3 & \begin{tabular}{l|}
3 \\
\end{tabular} & & \begin{tabular}{l|l}
3 & 3
\end{tabular} & 3 & 3 & \begin{tabular}{|l|l|}
3 & 3 \\
\end{tabular} & $75 \%$ \\
\hline Siswa ASK & 3 & 3 & & 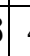 & t & 3 & 3 & 4 & 4 & 4 & 4 & 4 & 3 & 4 & 4 & 4 & 4 & 4 & $91,25 \%$ \\
\hline Siswa AFN & 4 & 4 & & 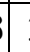 & 3. & 4 & 3 & 4 & 4 & 4 & 4 & 4 & 3 & 4 & 4 & 4 & 4 & 4 & $92,50 \%$ \\
\hline Siswa A & 4 & 4 & & 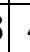 & ti & 4 & 3 & 4 & 4 & 4 & 4 & 4 & 4 & 4 & 42 & 4 & 4 & 4 & $96,25 \%$ \\
\hline Siswa DDP & 3 & 3 & & 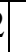 & 2 & 2 & 3 & 3 & 2 & 2 & 3 & 2 & 2 & & 3 & 3 & 3 & 3 & $65 \%$ \\
\hline Siswa DP & 4 & 4 & & 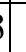 & $t$ & 3 & 3 & 4 & 4 & 4 & 4 & 4 & & & 4 & 4 & & 4 & $93,75 \%$ \\
\hline Siswa FYM & 4 & 4 & & & 4 & 4 & 3 & 4 & 4 & 4 & 4 & 4 & 3 & & 4 & 4 & 4 & 4 & $95 \%$ \\
\hline Siswa GMA & 3 & 3 & & & 3 & 3 & 3 & 3 & 4 & 4 & 4 & 4 & 2 & & 33 & 4 & 3 & 4 & $81,25 \%$ \\
\hline Siswa MRP & 3 & 3 & & & 3 & 2 & 3 & 2 & 3 & 3 & 3 & 3 & 2 & & 3 & 3 & 3 & 3 & $70 \%$ \\
\hline Siswa RA & 3 & 3 & & & t & 4 & & 4 & 4 & 4 & I & T & 4 & & 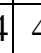 & 4 & & 4 & $93,75 \%$ \\
\hline Siswa SC & 3 & 3 & 2 & & 2 & 3 & 3 & 3 & 2 & 2 & 2 & 2 & & & 3 & 3 & 2 & 3 & $65 \%$ \\
\hline
\end{tabular}

Sumber: dokumen pribadi

Berdasarkan uji coba produk penelitian yang dikembangkan, didapatkan rata-rata persentase praktikalitas yang diperoleh dari angket siswa dan guru sebesar $84 \%$. Sehingga produk penelitian pengembangan masuk dalam kategori "Sangat Praktis". Terdapat komentar dari guru bahwa materi, latihan soal, dan asesmen sudah memadai. Kemudian ada komentar siswa yang menyatakan harapan agar produk penelitian dapat berkembang lebih baik.

Evaluasi adalah suatu langkah atau prosedur untuk mengukur sesuatu sesuai dengan aturan yang ditentukan (Muryadi, 2017). Pada tahap evaluasi, penelitian yang telah dilakukan terdapat beberapa kendala dan kekurangan, antara lain: (1) Kurangnya motivasi siswa untuk terlibat dalam penelitian; (2) Kurangnya pemahaman siswa terhadap materi prasyarat sebelum melangkah ke materi penelitian pengembangan yaitu grafik fungsi trigonometri; (3) Penulisan derajat pada latihan soal dan asesmen di Google Form tidak bisa ditulis sebagai "o" tetapi ditulis dengan kata "derajat" sehingga beberapa siswa bingung dengan penulisan tersebut; dan (4) Penulisan derajat dan akar pada kolom jawaban 
LKS Geogebra Book tidak dapat ditulis sebagai "o" dan " $\sqrt{ }$ " tetapi ditulis dengan kata "derajat" dan akar, sehingga beberapa siswa bingung dalam menulis jawaban.

Adapun produk penelitian yang dikembangkan telah melalui tahap analisis, desain, pengembangan, implementasi, dan evaluasi sehingga kelima tahap model penelitian ADDIE telah dilakukan secara lengkap.

Penelitian pengembangan ini merujuk dan mendukung penelitian yang telah dilakukan sebelumnya, antara lain: (1) Efektifitas Model Pembelajaran Problem Based Learning dan Quantum Berbantuan Geogebra terhadap Hasil Belajar Siswa pada Materi Trigonometri Kelas X. Penelitian ini dilakukan pada tahun 2019 oleh Nibras Belladina, Agung Handayanto, dan Ali Shodiqin; (2) Pengembangan Lembar Kerja Siswa (LKS) pada Mata Pelajaran Matematika Siswa Kelas X SMA. Penelitian ini dilakukan pada tahun 2017 oleh Astuti dan Nurhidayah Sari; (3) Pengembangan Perangkat Pembelajaran Menggunakan Deduktif Induktif Berbantuan Geogebra dalam Meningkatkan Kemampuan Berpikir Kreatif Siswa pada Masa Pandemi. Penelitian ini dilakukan pada tahun 2021 oleh Asep Ikin Sugandi, Deddy Sofyan, dan Siti Maesaroh.

Penelitian ini juga berkaitan dengan teori kognitif. Kegiatan pembelajaran dalam penelitian melibatkan siswa dalam memahami, mengolah informasi, serta memecahkan masalah ketika mempelajari materi grafik fungsi trigonometri, kemudian mengerjakan LKS, latihan soal, dan asesmen.

\section{SIMPULAN DAN SARAN}

Berdasarkan hasil penelitian dapat disimpulkan bahwa lembar kegiatan siswa (LKS) berbantuan Geogebra Book terdiri dari LK, latihan soal, dan asesmen yang dikembangkan memenuhi kriteria valid dan praktis untuk memudahkan siswa dan guru dalam proses pembelajaran. Adapun saran terhadap pengembangan produk penelitian yaitu dapat ditambahkan apersepsi (review materi prasyarat) serta ditambahkan petunjuk penggunaan LKS berupa contoh pengerjaan dalam soft file terpisah. Pengembangan produk penelitian lebih lanjut dapat dilakukan pada mata pelajaran dan materi lain. Serta dapat ditambahkan sub materi atau sub bab dalam produk penelitian.

\section{DAFTAR PUSTAKA}

Agustyaningrum, N., \& Gusmania, Y. (2017). Praktikalitas dan Keefektifan Modul Geometri Analitik Ruang Berbasis Konstruktivisme. Jurnal Dimensi, 6(3), 412-420. https://doi.org/10.33373/dms.v6i3.1075

Astuti, A., \& Sari, N. (2017). Pengembangan Lembar Kerja Siswa (LKS) pada Mata Pelajaran Matematika Siswa Kelas X SMA. Jurnal Cendekia : Jurnal Pendidikan Matematika, 1(2), 13-24. https://doi.org/10.31004/cendekia.v1i2.16

Azizul, S. M. J., \& Din, R. (2016). Teaching and Learning Geometry Using Geogebra Software via MOOC. Journal of Personalized Learning, 2(1), 39-50. http://spaj.ukm.my/jplearning/index.php/jplearning/article/view/31

Belladina, N., Handayanto, A., \& Shodiqin, A. (2019). Efektifitas Model Pembelajaran Problem Based Learning dan Quantum Berbantuan Geogebra terhadap Hasil Belajar Siswa pada Materi Trigonometri Kelas X. Imajiner: Jurnal Matematika Dan Pendidikan Matematika, 1(6), 323-331. https://doi.org/10.26877/imajiner.v1i6.4861

Cahyadi, R. A. H. (2019). Pengembangan Bahan Ajar Berbasis ADDIE Model. Halaqa: Islamic Education Journal, 3(1), 35-43. https://doi.org/10.21070/halaqa.v3i1.2124

Galicia, M. N., Poza, D., Pajares, J., \& López-Paredes, A. (2018). Implementation of Economic Models For Undergraduate Students with Geogebra. ICERI2018 Proceedings. Published. https://doi.org/10.21125/iceri.2018.0766

Hardani, et al. (2020). Metode Penelitian Kualitatif \& Kuantitatif . Yogyakarta: Pustaka Ilmu.

Horzum, T., Ünlü, M. (2017). Pre-Service Mathematics Teachers' Views about Geogebra and Its Use. Acta Didactica Napocensia, 10(3), 77-90. http://dx.doi.org/10.24193/adn.10.3.8 
Ismaraidha, I. (2021). Pengaruh Penggunaan LKS terhadap Prestasi Belajar Siswa pada Mata Pelajaran Pendidikan Agama Islam. Al-Fikru: Jurnal Ilmiah, 14(2), 100-107. https://doi.org/10.51672/alfikru.v14i2.39

Kemendikbud. (2020). Panduan Penyelenggaraan Pembelajaran pada Tahun Ajaran 2020/2021 dan Tahun Akademik 2020/2021 di Masa Pandemi Coronavirus Disease 2019 (Covid-19). Jakarta: Kemendikbud.

Lestari, A., Amelia, E., \& Marianingsih, P. (2018). Pengembangan Lembar Kerja Siswa Berbasis CTL (Contextual Teaching And Learning) Sebagai Bahan Ajar Siswa SMA/MA Kelas XII Subkonsep Kultur In Vitro. Biosfer: Jurnal Pendidikan Biologi, 10(1), 32-44. https://doi.org/10.21009/biosferjpb.10-1.5

Maharani, I., Nuraina, E., \& Astuti, E. (2021). Pengembangan Lembar Kerja Siswa (LKS) Berbasis Higher Order Thinking Skill (HOTS) dalam Mata Pelajaran Akuntansi Kelas X di SMK. JPAK: Jurnal Pendidikan Akuntansi dan Keuangan, 9(1), 1-9. https://doi.org/10.17509/jpak.v9i1.22266

Manurung, Sri H. (2015). Analisis Faktor-Faktor yang Mempengaruhi Keefektifan Belajar Matematika Siswa MTs Negeri Rantau Prapat Pelajaran 2013/2014. EduTech: Jurnal Ilmu Pendidikan dan Ilmu Sosial, 1(1), 1-16. http://dx.doi.org/10.30596\%2Fedutech.v1i01.269

Muryadi, A. D. (2017). Model Evaluasi Program dalam Penelitian Evaluasi. Jurnal Ilmiah PENJAS (Penelitian, Pendidikan dan Pengajaran), 3(1), 1-16. http://ejournal.utp.ac.id/index.php/JIP/article/view/538

Ningrum, E. (2016). Pengembangan Sumber Daya Manusia Bidang Pendidikan. Jurnal Geografi Gea, 9(1). https://doi.org/10.17509/gea.v9i1.1681

Nur, Isman M. (2016). Pemanfaatan Program Geogebra dalam Pembelajaran Matematika. Delta-Pi: Jurnal Matematika dan Pendidikan Matematika, 5(1), 10-19. http://dx.doi.org/10.33387/dpi.v5i1.236

Rahma, A. A., \& Arista, H. (2019). Pengaruh Model Pembelajaran Reciprocal Teaching Berbantuan LKS terhadap Prestasi Belajar Siswa. Musamus Journal of Science Education, 1(2), 053-059. https://doi.org/10.35724/mjose.v1i2.1452

Rohaeti, T., Pratiwi, I. (2021). Kecemasan Matematika Peserta Didik Di Era Covid-19 Dan Alternatif $\begin{array}{lll}\text { Solusinya. Integral: } & \text { Pendidikan } & \text { Matematika, 12(1), }\end{array}$ https://doi.org/10.32534/jnr.v12i1.1906

Rucitra, A. A. (2020). Merumuskan Konsep Desain Interior. Jurnal Desain $\quad$ Interior, 5(1), 3144. https://doi.org/10.12962/j12345678.v5i1.7020

Sari, I. P. (2018). Implementasi Model ADDIE dan Kompetensi Kewirausahaan Dosen terhadap Motivasi Wirausaha Mahasiswa. Jurnal Ekonomi Pendidikan dan Kewirausahaan, 6(1), 83-94. https://doi.org/10.26740/jepk.v6n1.p83-94

Sari, E., Rahmawati, Y., Vahlia, I. (2021). Pengembangan Bahan Ajar Matematika Berbasis Android dengan Pendekatan Realistic Mathematics Education (RME) Materi Koordinat Kartesius. EMTEKA: Jurnal Pendidikan Matematika, 2(1), 74-85. https://doi.org/10.24127/emteka.v2i1.764

Sarwa, S. (2021). Pembelajaran Jarak Jauh: Konsep, Masalah, dan Solusi. Indramayu: Penerbit Adab.

Sugandi, A.I., Sofyan, D., \& Maesaroh,S. (2021). Pengembangan Perangkat

Pembelajaran Menggunakan Deduktif Induktif Berbantuan Geogebra dalam Meningkatkan Kemampuan Berpikir Kreatif Siswa pada Masa Pandemi. JPMI - Jurnal Pembelajaran Matematika Inovatif, 4 (1), 149-160. http://dx.doi.org/10.22460/jpmi.v4i1.p\%25p

Susanto, E., \& Retnawati, H. (2016). Perangkat pembelajaran matematika bercirikan PBL untuk mengembangkan HOTS siswa SMA. Jurnal Riset Pendidikan Matematika, 3(2), 189-197. https://doi.org/10.21831/jrpm.v3i2.10631

Tampubolon, K., Saragih, H., Reza, B. (2013). Implementasi Data Mining

Algoritma Apriori pada Sistem Persediaan Alat-Alat Kesehatan. Majalah

Ilmiah Informasi dan Teknologi Ilmiah (INTI), 1(1), 93-106.

https://doi.org/10.17509/gea.v9i1.1681

Yaumi, M. (2018). Media dan Teknologi Pembelajaran. Jakarta: Prenadamedia Group. 